\title{
ALTERIDADE EM CONVERSA DE BOIS E CAMPO GERAL DE JOÃO GUIMARÃES ROSA
}

\section{OTHERNESS IN CONVERSA DE BOIS AND CAMPO GERAL BY JOÃO GUIMARÃES ROSA}

\author{
Salete Paulina Machado Sirino \\ Doutora Letras pela Universidade Estadual do Oeste do Paraná (UNIOESTE) \\ Docente e Diretora do Centro de Artes da Universidade Estadual do Paraná (FAP) \\ E-mail: saletems@uol.com.br
}

\section{RESUMO}

Entendendo a relevância da Leitura Literária no campo da Literatura e Ensino, neste artigo, promove-se o estudo sobre a concepção de Mikhail Bakhtin a respeito da língua e da interação social na construção da linguagem romanesca, por meio de análises dos textos de Guimarães Rosa, Conversa de Bois (1946) e Campo Geral (1956), utilizando-se como fundamentação teórica, especialmente, o livro Marxismo e Filosofia da Linguagem (1997), de Mikhail Bakhtin (Volochinov), no qual o autor expõe a sua teoria da linguagem e do dialogismo - diálogo entre o "eu" e o "outro". É esse caráter interativo da linguagem - a relação intersubjetiva entre os sujeitos sociais - que permeia a concepção de linguagem desse autor e que possibilita a análise proposta, tendo em vista que a linguagem na obra de Guimarães Rosa também remete a essa interação.

Palavras-chave: Leitura literária. Linguagem e Sociedade. Conversa de Bois e Campo Geral.

\begin{abstract}
Understanding the relevance of literary reading to the teaching of literature, this paper promotes the study of M Bakhtin's concept about language and social interaction on the language elaboration of novels, through the analysis of Guimarães Rosa's text, Conversa de Bois (1946), and Campo Geral (1956), based on Marxismo e Filosofia da Linguagem (1997), by Mikhail Bakhtin (Volochinov), in which the author exposes his theory about language and dialogism the dialog between oneself and the other. This interactive character of language - the intersubjective relationship between social subjects - that is part of this author's language conception allows the proposed analysis since language in Guimarães Rosa's work also reflects this interaction.
\end{abstract}

Keywords: Literary Reading. Language and Society. Conversa de Bois and Campo Geral. 


\section{LEITURA LITERÁRIA}

Qual é a relevância para um educador ou para um estudante da área de Letras de reflexões sobre a articulação entre teoria e prática de leitura literária? Pode-se chegar a resposta de que essa questão está amplamente discutida através das pesquisas já realizadas e pela prática acadêmica, como também concluir que - assim como outras questões voltadas ao estudo da Literatura, seja no campo da história, da teoria ou da crítica - a práxis da leitura literária é uma inesgotável fonte de pesquisa.

Partindo deste pressuposto e entendendo que a Literatura é construída essencialmente pela palavra ${ }^{1}$ e que o texto e o contexto ${ }^{2}$ presentes nela são apropriados e atualizados pelo leitor, neste artigo objetiva-se refletir sobre a leitura literária a partir de estudos de Mikhail Bakhtin (1997), tendo como objeto de análise o conto Conversa de Bois (1946) e a novela Campo Geral/Miguilim (1956), de João Guimarães Rosa.

Mikhail Bakhtin (1988) afirma que o dialogismo ocorre, inclusive, em textos literários. Em relação à metodologia de análise literária, ele levanta a questão da forma estrutura textual - como uma excessiva preocupação teórica em definir a obra de arte a partir de um formalismo extremo, ao qual o autor chamou de supervalorização do aspecto material. Para ele, a estética material - forma -, com a visão da literatura como algo puramente estético, a partir de sua estrutura formal, não dá conta de explicar a complexidade do trabalho artístico conteúdo. Bakhtin salienta que a obra de arte como algo material - e parte de sua constituição e de sua relação estética com o espectador passa, necessariamente, pela materialidade - não se restringe à obra em si, já que seus aspectos cognitivos, emotivos, históricos, ideológicos, extrapolam esta materialidade.

Considerando que o texto literário é construído pela palavra e, ainda, a visão bakhtiniana de que o homem é construído socialmente - alteridade -, sendo essa construção resultado da relação intersubjetiva entre os sujeitos sociais, a qual ocorre especificamente por meio da linguagem, a Literatura, por meio da leitura de seu texto e contexto, é um elemento relevante para a compreensão do homem e da sua interação com o mundo, mas também uma forma de compreender, no sentido aristotélico, a arte como "a imitação da vida interior dos homens, suas paixões, seu caráter, seu comportamento etc.” (HOUAISS, 2001, p. 1924).

No decorrer do século XX, a crítica literária, em relação à interpretação dos textos, evoluiu de teorias que primam pela compreensão do texto a partir das intenções do autor, passando pelos que privilegiam a análise do texto pelo próprio texto, chegando a teorias da recepção. Como afirma Eagleton (2001, p. 102): “De forma muito sumária, poderíamos 
periodizar a história moderna da teoria literária em três fases: uma preocupação com o autor (romantismo do séc. XIX), uma preocupação exclusiva com o texto (Nova Crítica) e uma acentuada transferência da atenção para o leitor nos últimos anos." Na tríade autor-texto-leitor, o leitor foi o menos privilegiado, fato que o próprio autor considera estranho, tendo em vista que sem o leitor não haveria textos literários.

É notória na linguagem romanesca de João Guimarães Rosa a inserção de aspectos regionais e universais na construção de suas obras. Sendo, portanto, evidente que esse autor, entre as décadas de 1930 a 1950, já tinha consciência de que a linguagem seria um elemento fundamental para captar o arcaico contexto social ao qual ele se reportou em sua obra como um todo. Tal construção torna possível a percepção de que a subjetividade de suas personagens é construída através da linguagem. É nesse sentido que se pretende aproximar os textos rosianos da teoria de linguagem de Mikhail Bakhtin, para quem a compreensão do signo linguístico considera o contexto social no qual os sujeitos falantes estão inseridos.

Objetivando a práxis da leitura literária do conto Conversa de Bois e da novela Campo Geral/Miguilim, dentre outros aspectos, pretende-se estudar em Conversa de Bois, a personagem protagonista Tiãozinho, descrito como "um pedaço de gente" (GUIMARÃES ROSA, 2001, p. 327), que, no final do conto, revela-se detentor de uma coragem surpreendente. Nesse conto, analisa-se, portanto, a construção da subjetividade de Tiãozinho, seu amor e compaixão pelo pai e seu ódio e desejo de vingança em relação ao patrão - amante de sua mãe.

Já na novela Campo Geral estuda-se a construção da subjetividade de Miguilim, a qual resulta da interação com seu espaço social - o Mutum. Assim, analisa-se a influência do regional e universal que o Mutum exerce sobre a formação da identidade de Miguilim, tendo em vista que Guimarães Rosa constrói o espaço como um elemento configurador da identidade de suas personagens.

\section{CAMPO GERAL E CONVERSA DE BOIS: LINGUAGEM E INTERAÇÃO SOCIAL}

Para Bakhtin, o signo linguístico é um signo social e ideológico que promove a interação social. O autor define a língua "como expressão das relações e das lutas sociais, veiculando e sofrendo os efeitos desta luta, servindo, ao mesmo tempo, de instrumento e de material”. (BAKHTIN, 1997, p. 17). Ou seja, língua e interação social estão interligadas, já que tal interação ocorre por meio da linguagem e esta é carregada de conotações ideológicas, uma vez que é a partir da palavra que as tensões e os conflitos sociais são gerados. 
Bakhtin (1997) evidencia que a linguagem é a matriz para a compreensão da consciência individual e que a consciência do homem é construída pela comunicação semiótica e pela interação com o seu grupo social, portanto, o universo verbal não pertence ao indivíduo, mas ao grupo local e ao ambiente social no qual ele está inserido. Bakhtin resgata Aristóteles ao propor que o homem nasceria duas vezes: a primeira como animal e a segunda como um ser social. Ou seja, o homem não nasce, apenas, como um organismo biológico abstrato, mas também como burguês ou proletário, como russo ou francês, etc., nasce, portanto, dentro de uma classe social, em um grupo e em uma pátria.

é uma forma ideológica particular da atividade mental do nós da classe burguesa (encontra-se um tipo análogo na classe feudal aristocrática). A atividade mental de tipo individualista caracteriza-se por uma orientação social sólida e afirmada. Não é do interior, do mais profundo da personalidade que se tira a confiança individualista em si, a consciência do próprio valor, mas do exterior; trata-se da explicitação do meu status social. (BAKHTIN, 1997, p. 117).

Para Bakhtin, não se pode acreditar na sinceridade subjetiva das concepções humanas, pois é nas interpelações de classe que se respalda toda a sua teoria. Assim, as respostas verbalizadas são uma formação, essencialmente social, o que o leva a crer que todas as falas humanas são produto de uma consciência de classe e não de indivíduos. O consciente e o inconsciente estão em constante interação, em estado de luta permanente entre si. "Assim, a personalidade que se exprime, apreendida, por assim dizer, do interior, revela-se um produto total da inter-relação social." (BAKHTIN, 1997, p. 117).

De acordo com Bakhtin (1997) a vida psíquica se apresenta ao homem de duas maneiras: a primeira adviria da experiência interior - vivências emocionais, concepções, sentimentos, desejos; a segunda adviria das experiências objetivas externas - causa-efeito fundamentadas na materialidade do que é externo, do que tem sentido na vida e na prática. Nas experiências externas o que corresponde às vivências interiores são "as palavras". Terry Eagleton (2001) argumenta que a linguagem para Bakhtin é resultado de uma prática social, portanto a interação social é a materialização da língua:

\footnotetext{
Além disso, como todos os signos eram materiais - tão materiais quanto os corpos ou os automóveis - e como não podia haver consciência humana sem eles, a teoria da linguagem de Bakhtin lançava as bases de uma teoria materialista da própria consciência. A consciência humana era o intercâmbio ativo, material, semiótico, do sujeito com outros sujeitos, e não um reino fechado, divorciado dessas relações; a consciência, como a linguagem, era, simultaneamente, "interior" e "exterior" ao sujeito. (EAGLETON, 2001, p. 161).
} 
Sendo a linguagem organizada pelo meio social no qual o indivíduo está inserido, logo, a autoconsciência é um complexo verbal: vejo a mim a partir dos outros - alteridade. $\mathrm{O}$ social dá ao homem as palavras e ele as une aos valores constituídos em sociedade. A subjetividade humana é construída socialmente. Eagleton conclui afirmando que para Bakhtin a interação social se dá por meio da interação verbal, ou seja, pelo diálogo ocorrido entre os sujeitos sociais. Se a dialogicidade é carregada de conotação social, a compreensão do enunciado, portanto, precisa considerar o contexto social dos falantes:

Assim, a teoria da expressão subjacente ao subjetivismo individualista deve ser completamente rejeitada. $\mathrm{O}$ centro organizador de toda enunciação, de toda expressão, não é interior, mas exterior: está situado no meio social que envolve o indivíduo. (BAKHTIN, 1997, p. 121).

Verifica-se que para Bakhtin a enunciação individual é um fenômeno essencialmente sociológico, por isso a estrutura da enunciação é uma estrutura puramente social, já que a enunciação só acontece entre os sujeitos falantes. O autor afirma que a filosofia marxista da linguagem deve ter como base de sua doutrina a enunciação como realidade da linguagem e como estrutura sócio-ideológica. Nas palavras de Terry Eagleton tem-se a representação da função de signo linguístico para Bakhtin:

\footnotetext{
Como tais avaliações e conotações modificam-se constantemente, já que a "comunidade linguística" era na verdade uma sociedade heterogênea composta de muitos interesses conflitantes, o signo para Bakhtin era menos um elemento neutro de uma estrutura qualquer do que um foco de luta e contradição. Não se tratava simplesmente de perguntar "o que significa o signo", mas de investigar sua diversidade histórica, na medida em que grupos sociais, classes, indivíduos e discursos conflitantes tentavam apropriar-se dele e impregná-lo de seus próprios significados. Em suma, a linguagem era um campo de luta ideológica, não um sistema monolítico. (EAGLETON, 2001, p. 160-161)
}

Terry Eagleton (2001) conclui que Bakhtin concebe o signo linguístico como um signo social e ideológico, resultado da relação intersubjetiva entre os sujeitos sociais, sendo a consciência individual constituída por meio da linguagem - da dialogicidade, o diálogo entre o "eu" e o "outro". Ou seja, a interação social que ocorre por meio da interação verbal reflete as ideologias de determinado indivíduo ou de determinada classe social.

Nesse aspecto, em Campo Geral (2001), de Guimarães Rosa, pela perspectiva de Miguilim, pode-se conhecer os conflitos existenciais das personagens que estão inseridas no espaço do sertão mineiro, em um lugarejo chamado Mutum. $\mathrm{O}$ foco narrativo dessa novela, por meio de sua estrutura sócio-ideológica, apresenta a infância de Miguilim, construída pelo autor através da interação social entre as personagens em geral, com destaque para Miguilim e Dito seu irmão mais novo. 
- 'Mas eu sei, que é mesmo. Aquilo que você perguntou." "- Então, quando você está com medo você também reza, Dito?' '- Rezo baixo, e aperto a mão fechada, aperto o pé no chão, até doer...' ' - Por que será Dito?' ' - Eu rezo assim. Eu acho que é por causa que Deus é corajoso.' (Campo Geral ${ }^{3}, 2001$, p. 98).

Percebe-se que os sentimentos de medo de Miguilim e Dito são superados pela crença na oração, no contato com Deus, um ser corajoso, capaz de protegê-los. Entende-se que o medo de Miguilim e Dito não é exclusivo a eles ou ao ambiente em que vivem. Guimarães Rosa, por meio da construção desse discurso literário, traz à tona um sentimento universal, já que o medo sentido por essas personagens pode provocar um efeito catártico ${ }^{4}$ no leitor, independente de ele ser criança ou adulto.

\begin{abstract}
O romance é uma diversidade social de linguagens organizadas artisticamente, às vezes de línguas e vozes individuais. [...] enfim, toda estratificação interna de cada língua em cada momento dado de sua existência histórica constitui premissa indispensável do gênero romanesco. E é graças ao plurilinguismo social e ao crescimento em seu solo de vozes diferentes que o romance orquestra todos os seus temas, todo o seu mundo objetal, semântico, figurativo e expressivo. (BAKHTIN, 1988, p. 74).
\end{abstract}

Para Bakhtin, o gênero romanesco possibilita a leitura de diversas vozes sociais. Nesse sentido, os textos de Guimarães Rosa propiciam a leitura de vozes de outros textos, por exemplo, em Campo Geral há uma intertextualidade bíblica: "Vovó Izidra xingava tio Terêz de "Caim" que matou Abel." (C.G., p. 42).

\begin{abstract}
Mas Vovó Izidra vinha saindo de seu quarto escuro, carregava a almofada de crivo na mão, caçando tio Terêz. - "Menino, você ainda está aí?!" -; ela queria que Miguilim fosse para longe, não ouvir o que ela ia dizer a tio Terêz. Miguilim parava perto da porta, escutava. O que ela estava dizendo: estava mandando tio Terêz fosse embora. Mais falava, com uma certa curta brabeza diferente, palavras raspadas. Forcejava que o tio Terêz fosse embora, por nunca mais, na mesma hora. Falava que por umas coisas assim é que há questão de brigas e mortes, desmanchando famílias. ( C.G., p. 41).
\end{abstract}

Guimarães Rosa lança o conflito - Miguilim escuta Vovó Izidra mandar tio Terêz embora. Então ele sente remorso por gostar do Tio Terêz e conclui que realmente o tio deveria ir embora. Do contrário, com o retorno do pai poderia haver uma desgraça na família. Os conflitos familiares aos quais Miguilim está exposto, em relação aos aspectos regionais do sertão de Minas Gerais, de certa forma desvelam as angústias e o doloroso processo de aprendizagem de Miguilim e este sentimento extrapola as bitolas do sertão. Percebe-se que o autor prenuncia a traição de Nhanina ${ }^{5}$ - mãe de Miguilim, com Tio Terêz, seu cunhado e tio de Miguilim e utiliza de sentimentos e atitudes humanas, de forma que o individual das personagens torna-se universal e, assim, possibilita a reflexão de famílias desestruturadas devido à traição. 
Em Campo Geral (2001), Guimarães Rosa promove a dialética entre o discurso interior e exterior das personagens, evidenciando como os comportamentos são modelados pelos valores sociais. Dessa forma, os comportamentos que escapam à ordem social estabelecida, como, por exemplo, o desregramento e a tendência ao adultério de Nhanina diverge do discurso oficial e, em função do seu poder desagregador, não pode ser exteriorizado e deve ser coibido. Miguilim, contudo, percebe esse desregramento e se decepciona com a atitude da mãe.

A situação de traição por parte da mãe - a atitude adúltera da mãe ameaça o universo da criança - que aparece na história de Miguilim em Campo Geral pode ser constatada, também, no conto Conversa de Bois. Nesse conto Guimarães Rosa narra a história da personagem Tiãozinho que vivencia sentimentos de medo e ódio por Agenor Soronho - amante de sua mãe:

Tiãozinho veio no grito, mas se mexendo encolhido, com medo de que o homem desse nele com a vara de ferrão. Falta de justiça, ruindade só. Foi o carreiro mesmo quem apertou a chaveta da cantadeira, hoje cedo; e até estava enjerizado, na hora, falando que Tiãozinho era um preguiçoso, que não prestava nem para ajeitar o carro nem para encangar os bois. (Conversa de Bois ${ }^{6}, 2001$, p. 337).

Guimarães Rosa evidencia o meio social em que esta personagem está inserida, a qual ainda criança de sete anos assume o trabalho de guia de carro-de-bois. Verifica-se, então, uma situação opressora de trabalho infantil, que chega ao extremo do patrão sentir-se no direito de agredir verbal e físicamente o empregado - criança -, caso este não cumpra o trabalho a seu contento.

Constata-se que a forma de agir de Agenor Soronho provoca em Tiãozinho medo - um medo duplo. Nessa relação, o poder ${ }^{7}$ está duplamente ao lado de Soronho, tanto porque em certa medida - por ser amante da mãe - sustenta a casa do menino, quanto pela força física que exerce sobre Tiãozinho, além, é claro, das relações de adulto opressor e criança oprimida, como era característico no contexto ao qual se reporta o autor. O patrão, sendo adulto, inibe qualquer possibilidade de reação, não restando a Tiãozinho outra alternativa do que temê-lo:

\footnotetext{
Ah, da mãe não gostava!... Era nova e bonita, mas antes não fosse... Mãe da gente devia de ser velha, rezando e sendo séria, de outro jeito... Que não tivesse mexida com outro homem nenhum... Como é que ele ia poder gostar direito da mãe?... Ela deixava até que o Agenor carreiro mandasse nele, xingasse, tomasse conta, batesse... Mandava que ele obedecesse ao Soronho, porque o homem era quem estava sustentando a família toda. Mas o carreiro não gostava de Tiãozinho... E era melhor, mesmo, porque ele também tinha ojeriza daquele capeta!...Ruço!... Entrão!... Malvado! (C.B., p. 339).
} 
Esse fato social ${ }^{8}$ - o adultério feminino -, embora de perspectiva diferente, é retomado por Guimarães Rosa na novela Campo Geral, e também nesta, este tema é percebido pelo olhar de Miguilim, assim como o fora por Tiãozinho em Conversa de Bois. Assim, este autor, por meio do texto literário, promove a reflexão da interação social que se dá a partir do discurso interior e exterior das personagens Tiãozinho e Miguilim, que sofrem com a atitude de suas mães.

Tiãozinho chamado pelos bois como bezerro do homem - parte da narrativa é percebida da perspectiva dos bois - acaba vingando a morte do pai antes mesmo de este ser enterrado. Em seguida, quando toma plena consciência de que, ao gritar com os bois, provocara a morte de seu Soronho, fica apavorado, pois seu desejo de vingar o sofrimento que o carreiro provocou para sua família, especialmente para ele e seu pai, projetado para o futuro já se confirmou no tempo presente, antes mesmo de seu pai ter sido sepultado.

Em Conversa de Bois há uma mescla do mundo fantástico com o mundo real, este é construído por meio de elementos daquele, pois o leitor é levado a fazer um pacto ficcional com o autor e acreditar que bois falam, pensam e, ainda, refletem sobre as ações humanas. Guimarães Rosa constrói seu conto dando vida e inteligência aos animais, inclusive, no próprio texto insere um personagem humano, Manuel Timborna, que não só acredita que animais falam, como pede licença para recontar um fato vivenciado pela Irara, a quem chama de Risoleta. Esta é descrita como uma moça séria e graciosa, se fosse mulher. A irara é, também, comparada a uma mulherzinha teimosa e que gosta de espiar, alusão à curiosidade feminina.

O sentido de palavra para Bakhtin (1997) - todas as tensões e todos os conflitos sociais são gerados por meio da palavra, é confirmado por Guimarães Rosa, tanto na história de Miguilim em Campo Geral (2001) quanto pela história de Tiãozinho em Conversa de Bois (2001). A palavra contida nesses textos é capaz de evidenciar as tensões, os conflitos familiares, especialmente, a tristeza de Miguilim e Tiãozinho pelas atitudes adúlteras e fracas de suas mães, algo que lhes tira a alegria de viver, lhes provoca um sentimento de insegurança perante o futuro:

\footnotetext{
'Batia. Batia, mas Miguilim não chorava. Não chorava, porque estava com um pensamento: quando ele crescesse, matava Pai. Estava pensando de que jeito era que ia matar Pai, e então começou a rir. Aí, Pai esbarrou de bater, espantado: como tinha batido na cabeça também, pensou que Miguilim podia estar ficando dôido. [...] E Miguilim chorou foi lá dentro de casa, quando Mãe estava lavando com água-com-sal os lugares machucados em seu corpo. - “Mas, meu filhinho, Miguilim, você, por causa de um estranho, você agride um irmão seu, um parente?” “- Bato! Bato é no que é pior, no maldoso!' Bufava. Agora ele sabia, de toda certeza: Pai tinha raiva com ele, mas Pai não prestava. (C.G., p. 135).
} 
Miguilim não gostava do pai e estava decepcionado com sua mãe, esta para ele, amava Luisaltino, e o pior, embora sofresse com ele, era fraca, não fora capaz de impedir que o pai batesse com tamanha crueldade no filho. Num rompante, porém, Miguilim limpa as lágrimas e decide nunca mais chorar e nem sentir medo de ninguém. Nota-se que a vivência concreta constrói a subjetividade desse menino, o ódio que Miguilim sente, especificamente, por seu pai, é resultado da forma como este o tratou.

$\mathrm{Na}$ análise dos textos de Guimarães Rosa, nota-se que a interação social das personagens não é apenas construída por meio da linguagem, mas também de que esta linguagem é uma representação social e histórica das mesmas. Dessa forma, esses textos proporcionam a leitura de um sertão mineiro onde estava estabelecida a ideologia do sistema patriarcal, em cujo estofo era permitido o trabalho infantil e a violência contra as crianças. Contudo, tal sistema estava em decadência, fato evidenciado em ambas as histórias pela traição aos maridos tanto pela mãe de Tiãozinho quanto pela mãe de Miguilim.

Em Campo Geral, a forma adúltera de agir de Nhanina, prenunciada pelo fato do bilhete do tio Terêz, é retomada, por Dito, que em seu leito de morte quer alertar o irmão mais velho, em segredo, dizendo que quando estavam sós, vovó Izidra a todo momento xingava a mãe, mas, o delírio febril não o deixa completar o segredo, e em seguida confessa ao irmão que sentia inveja por Papaco-o-Paco falar "Miguilim me dá um beijim" e não saber falar "Dito". Esse motivo leva Miguilim a ensinar sem sucesso o papagaio a pronunciar o nome de seu amado irmão Dito, nessa empreitada, pede ajuda a Rosa, que também fracassa, pois o papagaio só vai falar o nome do Dito depois que este já morreu.

Dito confessa ao irmão que queria ser um fazendeiro, ter grande quantidade de terra, com muito pasto e muitos bois. O vencedor naquele contexto é o dono da terra, o dono dos bois, e Miguilim diz ao irmão "você vai ter tudo o que quer"; talvez Miguilim seja tão ingênuo como as crianças costumam ser que acredite nisso ou, quem sabe, nesse momento, era preciso consolar o irmãozinho. "O Dito olhava triste, sem desprezo, do jeito que a gente olha triste num espelho. - 'Mas depois tudo quanto há cansa, no fim tudo cansa...” (C.G., p. 117).

A questão da consciência individual que Eagleton afirma, que para Bakhtin é uma construção social, pode ser constatada nos discursos interiores - a voz do pensamento - e exteriores - a palavra verbalizada - dos personagens Tiãozinho e Miguilim, respectivamente, em Conversa de Bois e em Campo Geral. "Faz um feitiço para ele não morrer, Mãitina! Faz todos os feitiços, depressa, que você sabe... Mas aí, no vôo do instante, ele sentiu uma coisinha caindo em seu coração, e adivinhou que era tarde, que nada mais adiantava". (C.G., p. 119). 
Nesse exemplo há uma mescla de discursos interior e exterior. Miguilim pede para Mãitina fazer feitiços para evitar a morte de seu amado irmão, essa situação objetiva evidencia a subjetiva - a extrema dor de Miguilim. A construção da consciência individual é clarificada pela representação da crença do povo em feitiços, bem como pela evidência da dor que a morte de um ente querido provoca.

Esse sofrimento também é vivenciado por Tiãozinho: "- Pobrezinho do menino!... exclama a moça do silhão". A tais palavras, Tiãozinho, que já estava meio quase consolado, recebe inteira, de volta, sua grande tristeza outra vez." (C.B., p.332). Em Conversa de Bois, Guimarães Rosa coloca em cena a situação de extrema tristeza em que uma criança é exposta, ela mesma tem que guiar o carro-de-boi que leva seu pai morto sobre as rapaduras e, o pior, o carro que leva o corpo de seu pai é do homem que em vida lhe provocou tristezas por sua condição de patrão que se sentia no direito, inclusive, de deitar-se com a sua mulher.

Toda essa situação conflitante é construída no imaginário do leitor por meio da palavra romanesca de Guimarães Rosa. É pela leitura desses textos que o leitor se identifica com a história e tem um sentimento catártico de compaixão em relação a Miguilim e a Tiãozinho, já que o autor mostra uma realidade em que as crianças acabavam sendo envolvidas no mundo dos adultos, sofriam com as dores de seus pais e com os erros de suas mães. Contudo, sofriam sozinhas, não havia o diálogo entre pai e filho, até porque em um sistema arcaico e patriarcal as crianças tinham responsabilidades de adultos, sem que seus sentimentos fossem considerados. A relação desses meninos com suas mães é construída de forma a evidenciar o amor deles por elas, mas estas, para eles, não são capazes de amá-los como eles as amam, pois não são capazes de defendê-los, como esperam, uma do próprio pai - Seo Bero - e a outra do amante - Seo Soronho.

Bakhtin (1997) clarifica que o homem não nasce como um organismo biológico abstrato, mas sim nasce dentro de uma classe social, em um tempo, em um lugar, em uma pátria, e só essa localização social e histórica do homem o torna real e lhe determina o conteúdo da criação da vida e da cultura.

Ao se analisar Campo Geral e Conversa de Bois, constata-se que Guimarães Rosa representa nestes textos literários essa localização social e histórica, possibilitando tanto a compreensão de um espaço regional - estruturado pelas características do sertão mineiro -, quanto por um espaço universal - caracterizado pelos sentimentos inerentes à condição humana das personagens. 


\section{O FICCIONAL COMO PORTA PARA REAL EM OBRAS ROSIANAS}

Na literatura de João Guimarães Rosa a língua é a principal forma de expressão dos sentimentos humanos e é através dela que o sertão converte-se em representação do mundo - do universal. Sendo este universal os sentimentos e conflitos inerentes à condição humana vividos por meio da linguagem literária e que serão re(vividos) no momento da fruição estética pelo receptor desta literatura.

Guimarães Rosa, tanto em Campo Geral quanto em Conversa de Bois, faz com que forma - estrutura textual - e conteúdo - temática -, sejam interligadas, especificamente, pela linguagem social que modela e condiciona as personagens historicamente situadas em seus respectivos contextos sociais, o que remete à concepção de Bakhtin de que a língua é resultado da interação social.

Assim, no ato da leitura de Campo Geral e Conversa de Bois, faz-se pertinente articular leituras paralelas sobre o contexto histórico-social vividos pelas personagens nestas obras em contraponto com o contexto histórico-social atual do receptor destas. Exemplo disso, o conceito sociológico de infância no sistema patriarcal no momento histórico no qual estas narrativas ocorrem é diferente da concepção sobre infância que se tem na atualidade. Ou seja, no tempo histórico romanesco, a forma como as personagens Tiãozinho e Miguilim eram vistas e tratadas seria natural, pois fazia parte daquela cultura. No contexto atual, essa visão seria dissonante em relação à mentalidade a respeito da infância, seja da perspectiva legal, seja da social. Entretanto, é relevante destacar que, ainda hoje, a despeito do Estatuto da Criança e do Adolescente e da mudança de mentalidade das famílias, há um grande contingente de crianças pobres ainda sujeitas a todo tipo de miséria, abuso e violência. Ou seja, para que vigore a lei e mudem os costumes é fundamental que haja as mínimas condições de sobrevivência, do contrário continuam em vigor os velhos costumes onde a sociedade exclui e a lei não alcança.

$\mathrm{Na}$ configuração espacial e social de Campo Geral, de Guimarães Rosa, impera um arremedo da estrutura patriarcal composta por pai, mãe, filhos, parentes e agregados - vovó Izidra, tio Terêz. Entretanto, esta estrutura, de fato, é apenas um arremedo, visto que Bero, o chefe da casa, está tentando fazer uma passagem da condição de miserável, vindo de uma estrutura caótica, à de remediado, com uma família estruturada, nos moldes da já decadente família patriarcal ${ }^{9}$.

Nessa tentativa de passar da condição de pobre para remediado, Bero trabalha de forma desesperada e impõe o rigor patriarcal na educação dos filhos. Contudo, há o agravante do comportamento infantil e erotizado de adolescente de Nhanina, mulher de Bero e mãe de 
Miguilim, que desestabiliza a família e expõe as crianças a um profundo desconforto e instabilidade, tanto é assim, que o seu comportamento imaturo será a fonte da tragédia que se abate sobre a família.

No conto Conversa de Bois (2001), também de Guimarães Rosa, o personagem protagonista Tiãozinho integra social e economicamente aquela massa de miseráveis ${ }^{10}$ socialmente invisível, como atesta o fato de, apesar de ser, apenas, um menino de sete anos "idade da razão" -, já trabalhar como candieiro e estar sujeito à tirania e à crueldade do carreiro e amante de sua mãe. Entretanto, naquela estrutura, cada um a seu modo, Miguilim e Tiãozinho são crianças tão determinadas e com tamanha opinião quanto os adultos. Miguilim demonstra isso ao enfrentar o pai em defesa da mãe, ao destruir todos os seus brinquedos, pondo fim à sua infância; ao ir embora apenas com oito anos em busca dos óculos e, simbolicamente, ao aprender a ver o mundo sem a mediação dos olhos do dito. Tiãozinho, ao vingar a humilhação e a morte do pai antes mesmo de este ser enterrado.

Tiãozinho segue o modelo de homem daquele universo - ele deseja crescer e mandar na mãe, ser dono de si e ter condições econômicas para manter-se e garantir a sobrevivência de sua família. Com o pai morto socialmente - mesmo antes de este ter morrido de fato - é Tiãozinho que, na estrutura social da família, irá assumir o papel de chefe, que durante a narrativa, é assumido pelo patrão, Agenor Soronho. Portanto, cabe a este menino de sete anos vingar a morte do pai e manter a família. Durante a viagem de Tiãozinho, seu fluxo de consciência revela a sua intenção de, quando crescer, poder mandar na casa, na mãe, assumir o lugar do pai - que em vida fora destituído do seu papel de chefe da família por Seo Agenor Soronho - e, principalmente, o maior de todos seus desejos: vingar-se do patrão não só pelos maus-tratos deste para com ele, mas, principalmente, pelas humilhações que causou ao seu pai.

Em Conversa de Bois e em Campo Geral, as contingências sociais são representadas pelo autor com ênfase no tom realístico. Entretanto, em sintonia com que sempre Guimarães Rosa se atém às condições humanas, paralelamente às duras circunstâncias nas quais estão inseridas as personagens infantis, há, também, claras referências ao mundo maravilhoso, como a auxiliar os meninos na dura e precoce passagem à condição de adultos.

Nestas obras rosianas percebe-se uma mescla do fantástico com o real, como uma representação do mundo da infância. Mundo este que transita entre o real - com seus dramas, violências e desgraças - e o imaginário mundo da fantasia, como é característico no universo infantil. Entretanto, indiscutivelmente, as fantasias infantis têm que ser rapidamente superadas à medida que as adversidades da vida desabam com toda a sua crueza sobre tais fantasias. Tanto é assim que Tiãozinho, com apenas sete anos, se vinga "quase sem querer", das humilhações sofridas pelo pai antes mesmo de este ser sepultado. 
Em Conversa de Bois, ocorre a relativização entre mundo real e mundo fantástico pela presença dos bois que falam, contam estórias e da irara Risoleta que "testemunha" a estória enfeitada do Timborna. Nesse texto os bois pensam e filosofam sobre a existência humana com certo tom de criticidade - nesse momento há a percepção da presença da visão do autor-empírico, Guimarães Rosa.

Em Campo Geral não há a presença explícita do fantástico, mas há a relativização da infância com a materialização da subjetividade de Miguilim, que é construída por meio dos pensamentos deste menino - seus medos da morte, do escuro, sua visão sobre os adultos e suas incertezas em relação ao futuro.

Nesta novela tudo que o narrador diz é da perspectiva do pensamento de Miguilim ou das suas ações e diálogos com as demais personagens. Em relação a Miguilim, além de o narrador acompanhar sua estória e seus pensamentos no tempo presente da narrativa, ele recorre aos flashbacks para mostrar as primeiras lembranças de Miguilim, quando ele ainda estava começando a andar. Tais flashbacks têm o intuito de fazer remissão às primeiras lembranças da personagem.

Tanto a inserção da rememoração quanto das ações paralelísticas que caracterizam as personagens e o espaço onde estão situadas, contribuem para a construção detalhada da história de Miguilim. Essa estratégia narrativa vincula-se ao contexto cultural no qual o autor situa temporalmente e espacialmente a personagem e sua família.

Sendo assim, há a percepção da forma como a criança era vista e tratada; da maneira autoritária como Bero conduz a família; das situações que envolvem o caráter imaturo de Nhanina, como se este fosse uma espécie de herança legada por sua mãe Benvinda, que fora prostituta, mas principalmente, tal comportamento remete àquela massa "sem eira nem beira", da qual fala Antonio Cândido; da relação quase mágica e interdepende de Miguilim com Dito; do aprendizado de Miguilim sobre a dor da saudade e a presença da morte que leva ao seu merencório amadurecimento precoce; do mundo sertanejo dos vaqueiros; da crença na religião católica, representada especialmente por vovó Izidra; das heranças culturais e religiosas africanas de Mãitina; da preocupação com a educação percebida pelo fato de Liovaldo morar com outra família para poder estudar, bem como pelo fato de Miguilim, no final da novela, ir embora com o doutor em busca da visão e também com o objetivo de estudar e ter uma melhor condição econômica e social de vida, ou seja, ter ampliada, em todos os sentidos, sua visão de mundo. Ele vai transpor os morros do Mutum que tampavam a visão de sua mãe.

Em Campo Geral, Guimarães Rosa evidencia, ainda, um rito de passagem, o qual é construído por meio da viagem. É entre a volta da viagem que Miguilim fez com tio Terêz para ser crismado e a de sua ida embora de vez do Mutum, levado pelo doutor, que é narrada a 
história de Miguilim. Essa história não narra apenas a passagem dos sete para os oito anos dessa personagem, mas também a passagem abrupta e traumática da infância para a vida adulta, sem passar pela transição da adolescência.

Em Conversa de Bois e em Campo Geral a presença do discurso objetivo como também do subjetivo, remete ao fluxo de consciência, em especial de Tiãozinho e Miguilim, personagens crianças que percebem estarem à mercê do comportamento muitas vezes ininteligível dos adultos. É nisto que Dito é dissonante e sábio, visto que ele, como prenuncia seu nome, já nascera sabendo entender o intricado e confuso mundo dos adulto, bem como a complexidade da vida. Ou seja, Guimarães Rosa expressa não só a linguagem verbalizada de seus personagens, mas também através do fluxo de consciência, o que possibilita ao leitor a percepção da subjetividade - os sentimentos - dos mesmos.

Constata-se, então, que, na construção narrativa rosiana, há representação da linguagem do meio social no qual seus personagens estão inseridos. Nos discursos de Miguilim e Tiãozinho ambos têm o seu "eu" formado por suas vivências sociais. Tal estratégia narrativa propicia a aproximação de tais obras rosianas da teoria de linguagem - dialogicidade - de Bakhtin, para quem o "eu” é construído na relação com o “outro", especificamente, por meio da palavra.

\section{NOTAS}

1 Para Bakhtin a palavra é o fenômeno ideológico por excelência, sendo que toda palavra é absorvida por sua função de signo. "A palavra não comporta nada que não esteja ligado a essa função, nada que não tenha sido gerado por ela. A palavra é o modo mais puro e sensível de relação social." (BAKHTIN, 1997, p. 36).

2 Antonio Candido no livro Literatura e Sociedade: estudos de teoria e história literária (2010), afirma que Texto e Contexto são fundidos e tornam-se a estrutura literária: a realidade social contexto - é materializada pelo texto - narrador, enredo, personagens, tempo e espaço possibilitando, ao leitor, tanto o conhecimento do mundo narrado pela obra, quanto a possibilidade de reflexão e de questionamento do mundo real que esta obra materializa.

3 Todas as citações do conto Campo Geral, referem-se a: ROSA, João Guimarães.

4 Identificação emocional do leitor frente ao drama vivenciado pelo personagem.

5 Também a origem da família materna de Miguilim revela a fragilidade da sua institucionalização, uma vez que sua avó materna fora prostituta. "Um vaqueiro contou ao Dito, de segredo, Vó Benvinda quando moça tinha sido mulher-à-toa. Mulher-à-toa é que os homens vão em casa dela e ela quando morre vai para o inferno" (C.G., p. 478). Portanto, Guimarães Rosa, ao criar a personagem Nhanina, faz remissão àquela massa amorfa e caótica, sem eira nem beira, que vivia e parte ainda vive - de déu em déu pelas áreas rurais ou pelas periferias urbanas brasileiras. (FORTES, 2009, p. 03).

6 Todas as citações do conto Conversa de Bois, referem-se a: ROSA, João Guimarães. 
7 Para Michel Foucault (1979) o poder não existe apenas na relação "dominante versus dominado" existe uma circularidade, o poder funciona em rede, ou seja, os indivíduos estão sempre em posição de exercer o poder ou de submeter-se a ele.

8 Em As Regras do Método Sociológico (1978), Émile Durkheim afirma que todo modo de ser e de agir do indivíduo em sociedade é considerado como um fato social, o qual é conhecido pelo poder de coerção externa que exerce ou é passível de exercer sobre o outro.

9 A família patriarcal compunha-se não somente de casais subordinados ao chefe, mas incluíam a família os servos ou agregados, os escravos, as crianças de todos, das quais eram recrutadas as amantes ocasionais e as concubinas dos homens brancos e, entre os quais viviam as crianças nascidas de tais união. (CANDIDO, Antonio, 1951, p. 07).

10 Com a cessação das bandeiras e a corrida do ouro, a massa de dependente de homens livres desempregados, a maioria deles mestiços, ficou gradualmente separados dos grupos que mantinham, isto é, das famílias patriarcais às quais serviam como agregados e tornaram-se um estrato social amorfo e anônimo. (CANDIDO, Antonio, 1951, p. 09).

\section{REFERÊNCIAS}

BAKHTIN, Mikhail. Questões de Literatura e de Estética: a teoria do romance. Tradução de Aurora Fornoni Bernardini et. al. São Paulo: HUCITEC, 1988.

BAKHTIN, Mikhail (Volochinov). Marxismo e Filosofia da Linguagem. Tradução de Michel Lahud e Yara Frateschi Vieira et. al. São Paulo: HUCITEC, 1997.

CANDIDO, Antônio. Literatura e Sociedade: estudos de teoria e história literária. $8^{\text {a }}$ edição. São Paulo: T. A. Queiroz, Editor, Ltda., 2000.

CANDIDO, Antonio. The Brazilian family. In: SMITH, Lynn; MARCHANT, Alexander (orgs.). Brazil: portrait of half a continent. New York: The Dryden Press, 1951, p. 291-311.

COELHO, Nely Novaes. Os contos de fadas. São Paulo: Ática, 1991

EAGLETON, Terry. Teoria da Literatura: uma introdução. Tradução de Waltensir Dutra. São Paulo: Editora Martins Fontes, 2001.

FORTES, Rita Felix. Campo Geral: um tristonho arremedo de casa-grande. In: Anais de $12^{\mathrm{a}}$ Jornada de Estudos lingüísticos e literários. Marechal Cândido Rondon: Assoeste: 2009. ( no prelo)

FORTES, Rita Felix. ZANCHET, Maria Beatriz. Sabor e Saber: o lugar do conto na escola. Foz do Iguaçu: Editora Parque, 2007.

GUÉRIOS, Rosário Farâni Mansur. Dicionário Etimológico de Nomes e Sobrenomes. 3. ed., São Paulo: Editora Ave Maria Ltda., 1981.

HOUAISS, Antônio et. al. Dicionário da língua portuguesa. Rio de Janeiro: Objetiva, 2001.

ISER, W. O Ato da Leitura: uma teoria do efeito estético. Tradução de Johannes Kreschmer São Paulo: Ed. 34, 1996. 
JAUSS, Hans Robert. A história da literatura como provocação à teoria literária. Tradução Sérgio Tellaroli. São Paulo: Ática, 1979.

ROSA, João Guimarães. Campo Geral In: Manuelzão e Miguilim (Corpo de baile). Rio de Janeiro: Nova Fronteira, 2001.

ROSA, João Guimarães. Conversa de bois. In . Sagarana. Rio de Janeiro, Nova Fronteira, 2001. 